\title{
Trend Analyses of Parameters of Equations for Energy Consumption Ratio Achievable in Ubicomp MANET Using Location-Aware Transmission.
}

\author{
M. Kaleem GALAMALI, Assoc. Prof Nawaz MOHAMUDALLY
}

\begin{abstract}
A good future lies ahead as concerns research related to location-tracking, ubicomp functionalities and MANET transmission strategies [34-70]. Despite all present level progresses, the area of modelling in ubicomp to assess predictability features is being tackled by few researches and is hence still considered in its embryonic stages. One particular sub-area is energy considerations in ubicomp coupled by the fact that battery power is still considered constrained. A previous research was carried out to quantify and model the ratio of energy consumption for each node over the energy consumed by the sender, for node densities of 7 until 56. The corresponding model was observed to be linear previous to the peak value and asymptotically decreasing exponential as from the peak value onwards.
\end{abstract}

In this paper, the next level of research investigation is put forward as: "What are the trends of variation observable within each parameter of the equations of curves obtained for metric ECR [18] over varying node densities?"

The need for studying the behaviour of components of an applicable model for metric ECR and correspondingly model the behaviour of each component mathematically is required since it involves lots of efforts and conflict resolution between different researchers. Results obtained will assist designers towards better understanding of ubicomp and provision hardware, software and algorithmic support for ubicomp architectures. This paper is a follow-up of previous research [1-33].

Key terms: Ubicomp- Ubiquitous Computing, MAUCMobile and Ubiquitous Computing, MANET- Mobile Adhoc Network, CBR- Constant Bit Rate, ECR- Energy Consumption Ratio

M. Kaleem GALAMALI,

University of Technology Mauritius (student) Mauritius

Assoc. Prof Nawaz Mohamudally University of Technology Mauritius, Mauritius

\section{Introduction}

MANET transmission is considered as a solution to poor resource availability in ubicomp. It does affect the distribution of energy consumption in ubicomp environment [2]. This feature is heavily influenced by node density. A previous study [18] was aimed at finding the trends observable for metric ECR for varying node densities of 7 until 56. The model suggested in that paper [18] was split into two:

- A straight line $\mathrm{F}(\mathrm{x})$ from left of the graph towards right until a peak value (at around ECR value 0.3)

$$
F(x)=d^{\star} x+f
$$

- As from the peak value, the trend is smoothly exponentially decreasing towards asymptotic to the $\mathrm{X}$-axis

$$
G(x)=a * \exp (b *(x-c))
$$

Here, the equations of the model have involved five parameters: $a, b, c, d$ and $f$. The next achievement in this research for metric ECR is to study the mathematical modelling of the parameters of the equations elicited above and accordingly deriving the model of variation of each parameter.

The key contributions of this paper is the establishment of the trend of variation for each parameter of the equations involved in the model for metric ECR presented in previous paper [18]. Re-use of tabular data in Table 1 in that paper [18] covering node numbers 7 until 56, is carried out here. The mathematical methods produced here may be programmed into software simulators and provide a tool for designers to better understand the evolution and predictability of ubicomp features to assist in provisioning of future ubicomp needs. The rest of this paper is organised as follows: section 2- Parameter Trend Analysis- Metric ECR, section 3- Conclusion and References.

\section{Parameter Trend Analysis - Metric ECR. \\ 2.0 General Procedure Adopted.}

The tabulated data for each parameter of equation of model for ECR is plotted on gnuplot. Graphical analyses using the "fit" command is performed supported by the smooth bezier plot. For each graph obtained, the general observations are reported. Again, various equations of fit are attempted and their summary report is presented for each parameter of metric ECR. In the end, choice is made considering firstly value of least reduced chi-square and secondly on most plausible extendability produced at node 
numbers 80, 100 and 120. Finally, values of parameters for each ECR parameter of equation is also noted.

\subsection{Trend Analysis - ECR parameter " $a$ ".}

The curve depicts a rapid drop from node number 7 until about 14, then shows an increasing tendency towards flattening at about node number 43 and then continues with a slowly decreasing tendency. The curve is not a clean oscillation nor has symmetrical properties. Exponential and logarithmic trends are combined here.

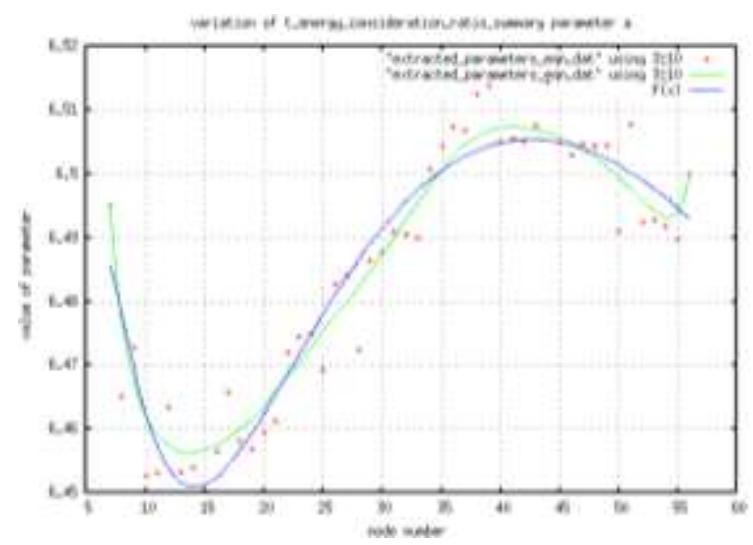

Figure 1: ECR parameter a

A summary of potentially applicable equations of trend is provided below:

$$
\begin{aligned}
& \text { 1. } F(x)=\left(a^{*}(x-d)^{k}\right) /\left(\exp \left(\left(b *(x-d)^{h}\right)+c\right)\right) \\
& +f^{*}(x-d)^{-2} * \log (x) \\
& \text { Ch_sq }=4.57146\left(\mathrm{e}^{-05}\right) \quad \mathrm{F}(80)=6.461169549 \\
& \mathrm{~F}(100)=6.418915272 \quad \mathrm{~F}(120)=6.372342420 \\
& \text { Ch_sq }=4.11043\left(\mathrm{e}^{-05}\right) \quad \mathrm{F}(80)=6.428815497 \\
& \mathrm{~F}(100)=6.355111966 \quad \mathrm{~F}(120)=6.273719
\end{aligned}
$$

3. $F(x)=1 * x^{3}+m * x^{2}+n * x+o$

$$
\begin{array}{ll}
\text { Ch_sq }=5.23371\left(\mathrm{e}^{-05}\right) & \mathrm{F}(80)=6.1174198 \\
\mathrm{~F}(100)=5.307807 & \mathrm{~F}(120)=3.8380
\end{array}
$$

4. $F(x)=1 *(x-p)^{3}+m *(x-p)^{2}+n *(x-p)+o$

$$
\begin{array}{ll}
\text { Ch_sq }=5.35002\left(\mathrm{e}^{-05}\right) & \mathrm{F}(80)=6.117422 \\
\mathrm{~F}(100)=5.307815 & \mathrm{~F}(120)=3.838058
\end{array}
$$

\section{Choice of best fit for ECR parameter a}

The equation in part 2 above has been selected because of both smallest reduced chi-square value obtained and good extendability. The parameters for best fit are:

$\mathrm{a}=11.972, \mathrm{~b}=77.2973, \mathrm{c}=-75.6539, \mathrm{~d}=-3.31317$ , $\mathrm{f}=32.0114, \mathrm{~h}=0.0362682, \mathrm{i}=1.64725, \mathrm{k}=$ 3.26836.

\subsection{Trend Analysis - ECR parameter " $b$ ".}

The curve depicts a rapidly increasing value towards reaching a maximum turning point at node number 20 after which a mild shade of damped oscillation with decreasing amplitude spread over wide range of node numbers. Curve does not show symmetrical properties.

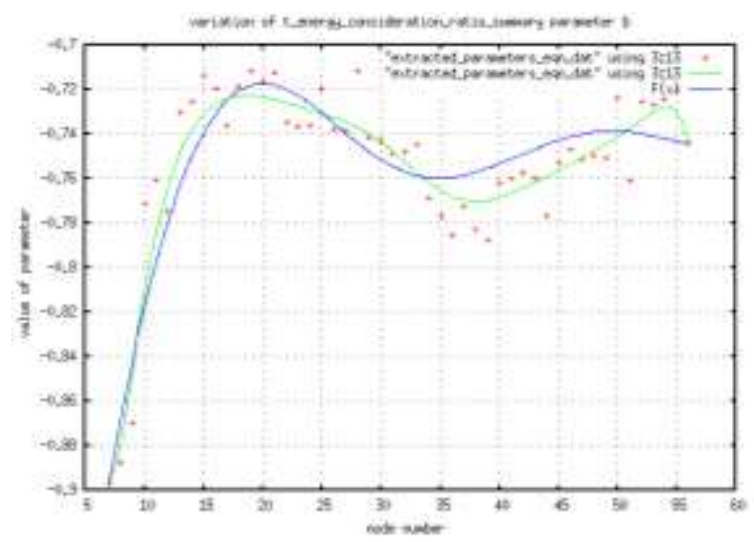

Figure 2: ECR parameter $b$

A summary of potentially applicable equations of trend is provided below:

$$
\begin{array}{rl}
\text { 1. } & F(x)=a * \sin (b * x)+C \\
\text { Ch_sq }=0.000908151 & F(80)=-0.726310908 \\
F(100)=-0.788728752 & F(120)=-0.746401523 \\
\text { 2. } \quad F(x)=(a / x) \star \sin & (b * x)+C \\
\text { Ch_sq }=0.000397595 & F(80)=-0.738420 \\
F(100)=-0.753486 & F(120)=-0.752390747 \\
\text { 3. } \quad F(x)=a \star x^{d} \star \sin & (b * x)+c \\
\text { Ch_sq }=0.000358 & F(80)=-0.742766 \\
F(100)=-0.7466308 & F(120)=-0.748413
\end{array}
$$

\section{Choice of best fit for ECR parameter $b$}

The equation in part 3 above has been selected because of both smallest reduced chi-square value obtained and good extendability. The parameters for best fit are:

$\mathrm{a}=-2.82055, \mathrm{~b}=0.219344, \mathrm{c}=-0.746475, \mathrm{~d}=-$ 1.50557

\subsection{Trend Analysis - ECR parameter " $c$ ".}

The curve depicts an oscillation with minimum point at node number 15 and maximum point at node number 41. The curve does not show symmetrical properties.

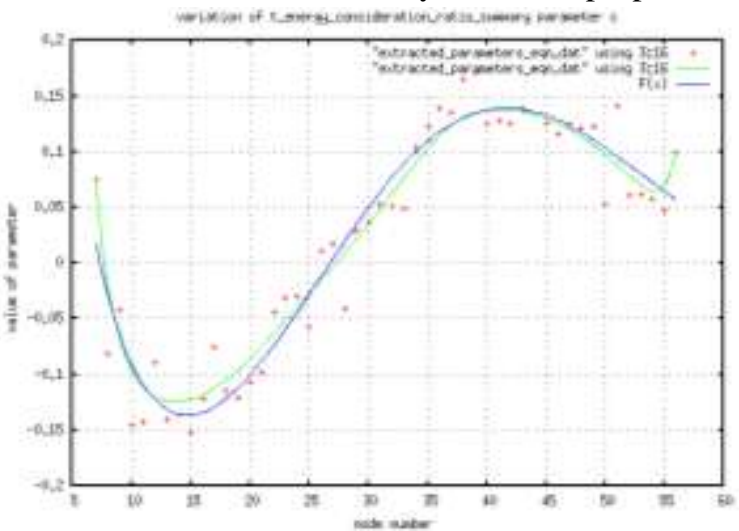

Figure 3: ECR parameter c 
A summary of potentially applicable equations of trend is provided below:

1. $F(x)=a * x^{3}+b * x^{2}+c * x+d$

Ch_sq $=0.0013829$

2. $F(x)=a * x^{3}+b * x^{2}+c * x+(d * x) / \exp (x)$

$$
\begin{array}{ll}
\text { Ch_sq }=0.000901577 & F(80)=-1.563695 \\
F(100)=-5.01069 & F(120)=-11.208026
\end{array}
$$

3. $F(x)=a * \sin (b * x)+d$

$$
\begin{array}{ll}
\text { Ch_sq }=0.00123968 & F(80)=-0.057833 \\
F(100)=0.148319 & F(120)=-0.057993
\end{array}
$$

4. $F(x)=a * \sin (b *(x-c))+d$

$$
\begin{array}{ll}
\text { Ch_sq }=0.00121465 & F(80)=-0.029634 \\
F(100)=0.145116 & F(120)=-0.0960095
\end{array}
$$

5. $\quad F(x)=a * x \star \sin (b *(x-c))+d$

$$
\text { Ch_sq }=0.00158181 \quad \mathrm{~F}(80)=-0.413238330
$$$$
\mathrm{F}(100)=0.197394 \quad \mathrm{~F}(120)=0.368505
$$

6. $F(x)=a * \log (x) \star \sin (b *(x-c))+d$ Ch_sq $=0.00130848 \quad \mathrm{~F}(80)=-0.118045820$

$\mathrm{F}(100)=0.185035948 \quad \mathrm{~F}(120)=-0.073590$

7. $F(x)=(a / x) * \sin (b *(x-c))+d$

Ch_sq $=0.000 \quad 840 \quad \mathrm{~F}(80)=0.061816010$

$\mathrm{F}(100)=0.079216 \quad \mathrm{~F}(120)=0.036205056$

8. $\quad F(x)=a * x^{f} * \sin (b *(x-c))+d$

Ch_sq $=0.000851317 \quad \mathrm{~F}(80)=0.064518$

$\mathrm{F}(100)=0.080213 \quad \mathrm{~F}(120)=0.044621$

\section{Choice of best fit for ECR parameter c}

The equation in part 7 above has been selected for smallest ch_sq and good extendability. The parameters of best fit are:

$a=-3.30223, b=0.127968, c=6.26447, d=0.0613619$

\subsection{Trend Analysis - ECR parameter " $d$ ".}

The curve depicts generally an increasing tendency with some unclean non symmetrical oscillations.

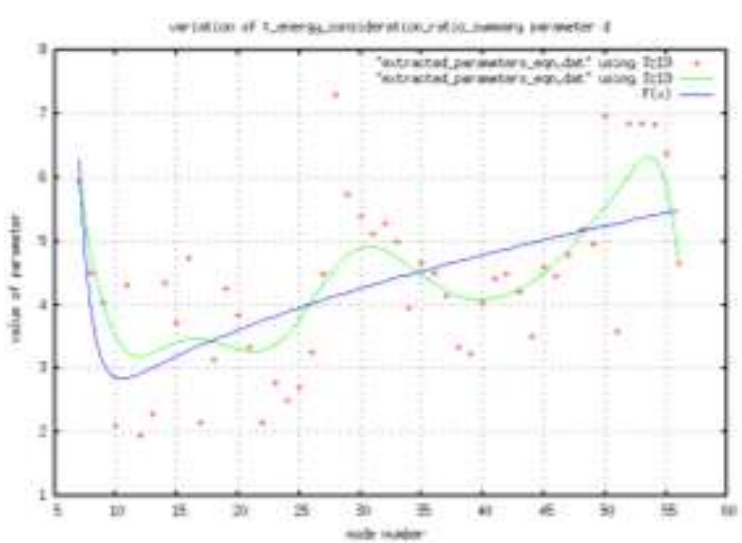

Figure 4: ECR parameter d
A summary of potentially applicable equations of trend is provided below:

$$
\begin{aligned}
& \text { 1. } F(x)=d * x+f \\
& \begin{array}{ll}
\text { Ch_sq }=1.40534 & \mathrm{~F}(80)=6.553 \\
\mathrm{~F}(100)=7.467 & \mathrm{~F}(120)=8.3809
\end{array}
\end{aligned}
$$

2. $F(x)=d * x+(f / x)$

$$
\begin{array}{ll}
\text { Ch_sq }=1.26156 & \mathrm{~F}(80)=8.164 \\
\mathrm{~F}(100)=10.041 & \mathrm{~F}(120)=11.942895
\end{array}
$$

3. $F(x)=a * x+(b / \exp (x))+c$

$$
\begin{array}{ll}
\text { Ch_sq }=1.20762 & \mathrm{~F}(80)=7.034015658 \\
\mathrm{~F}(100)=8.189198 & \mathrm{~F}(120)=9.344381708
\end{array}
$$

4. $F(x)=a \star x+b /\left(x \star \exp \left(c^{\star} x^{d}\right)\right)$

$$
\begin{array}{ll}
\text { Ch_sq }=1.32217 & \mathrm{~F}(80)=7.926667 \\
\mathrm{~F}(100)=9.979631957 & \mathrm{~F}(120)=12.342619
\end{array}
$$

5. $F(x)=a \star x+\left(b /\left(x^{*} \exp \left(c^{\star} x^{d}\right)\right)\right)+f$

$$
\text { Ch_sq }=1.26329 \quad \mathrm{~F}(80)=7.262
$$

$\mathrm{F}(100)=8.5403195 \quad \mathrm{~F}(120)=9.818652$

6. $F(x)=a \star x+b /(\exp (x))+c \star \log (x)$

$$
\text { Ch_sq }=1.23504 \quad \mathrm{~F}(80)=6.401732374
$$$$
\mathrm{F}(100)=7.080460367 \quad \mathrm{~F}(120)=7.716057421
$$

\section{Choice of best fit for ECR parameter $d$}

The equation in part 6 above has been selected even if its reduced ch_sq is not smallest; its extendability is more stable. The parameters of best fit are:

$a=0.0221482, b=4469.27, c=1.05656$

\subsection{Trend Analysis - ECR parameter " $f$ ".}

Generally the curve depicts a decreasing tendency with some slight oscillations. The curve does not show symmetrical properties.

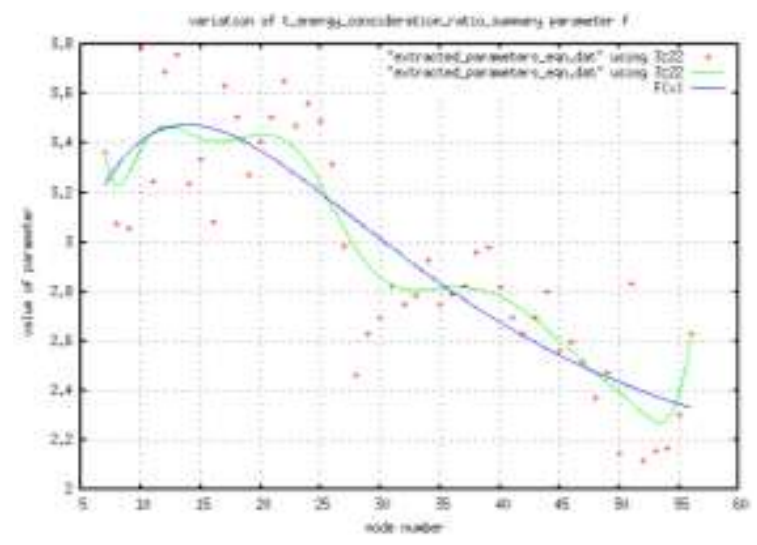

Figure 5: ECR parameter $f$

A summary of potentially applicable equations of trend is provided below:

$$
\begin{array}{rr}
\text { 1. } F(x)=d * x+f & \\
\text { Ch_sq }=0.0657975 & F(80)=1.668744035 \\
F(100)=1.142174472 & F(120)=0.615604908 \\
\text { 2. } & F(x)=a / \exp ((b * x)+c)+d
\end{array}
$$




$$
\begin{aligned}
& \text { Ch_sq }=0.0695186 \quad \mathrm{~F}(80)=1.768888961 \\
& \mathrm{~F}(100)=1.341777667 \quad \mathrm{~F}(120)=0.943264949 \\
& \text { 3. } F(x)=a / \exp \left(\left(b * x^{0.75}\right)+c\right)+d \\
& \text { Ch_sq }=0.0729808 \quad \mathrm{~F}(80)=1.898321 \\
& \mathrm{~F}(100)=1.552367555 \quad \mathrm{~F}(120)=1.234098811 \\
& \text { 4. } F(x)=(a * x) / \exp ((b * x)+c)+d \\
& \text { Ch_sq }=0.0580595 \quad \mathrm{~F}(80)=2.125580666 \\
& \mathrm{~F}(100)=2.077057266 \quad \mathrm{~F}(120)=2.062519946 \\
& \text { 5. } F(x)=\left(\left(a^{\star} x^{f}\right)+h\right) / \exp ((b * x)+c)+d \\
& \text { Ch_sq }=0.0655105 \quad \mathrm{~F}(80)=1.430777002 \\
& \mathrm{~F}(100)=0.832043412 \quad \mathrm{~F}(120)=0.288542710 \\
& \text { 6. } F(x)=\left(a * x^{f}\right) / \exp ((b * x)+c)+d \\
& \text { Ch_sq }=0.059137 \quad \mathrm{~F}(80)=2.198520 \\
& \mathrm{~F}(100)=2.170586 \quad \mathrm{~F}(120)=2.164044
\end{aligned}
$$

\section{Choice of best fit for ECR parameter $f$}

The equation in part 4 above has been selected because of smallest reduced chi-square value obtained and good extendability. The parameters for best fit are:

$\mathrm{a}=0.013973, \mathrm{~b}=0.0722522, \mathrm{c}=-2.99216, \mathrm{~d}=$ 2.05679

\section{Conclusion.}

This piece of research was aimed at and has developed the applicable models of trends of the parameters of equations for the metric ECR in a MANET topography of $300 \times 300 \mathrm{~m}^{2}$. The models put forward comprise of advanced mathematical equations which may assist in studying MANETs for MAUC environment from a software engineering view. The proposed mathematical procedure can be used to formulate computational algorithms to be integrated in software simulators for appropriate studies of MANET evolutions. The experiments here were executed in NS-2 over linux. The plottings and "fit" attempts were carried out in gnuplot. Criteria used for evaluating best fit remain smallest reduced chi-square values and best extendability of equations obtained.

Assumptions stated in previous paper [18] are carried forward here also. The applicability of gnuplot and its accuracy levels for such studies is also assumed as correct.

Further work identified remain: formulating methods of predictability for metric ECR and its trend and reporting observations of certain critical values identified.

\section{References}

[1] M. Kaleem GALAMALI, Assoc. Prof Nawaz MOHAMUDALLY, Towards Dependable Pervasive
Systems-A Position and Vision Paper, CEET 2014

[2] M. Kaleem GALAMALI, Assoc. Prof Nawaz MOHAMUDALLY, Model of Energy Savings achievable with Location-aware Node-to-Node Transmission in UbiComp , CEET 2014

[3] M. Kaleem GALAMALI, Assoc. Prof Nawaz MOHAMUDALLY, Model of Energy Savings achievable with Location-aware Node-to-Node Transmission in UbiComp Using Location Refresh Intervals, CEET 2014

[4] M. Kaleem GALAMALI, Assoc. Prof Nawaz MOHAMUDALLY, Model of Energy Savings achievable with Location-aware Transmission in UbiComp Using Relays, CEET 2014

[5] M. Kaleem GALAMALI, Assoc. Prof Nawaz MOHAMUDALLY, Mathematical modeling of need of exact number of relays to ensure seamless mobility in mobile computing, CEET 2014

[6] M. Kaleem GALAMALI, Assoc. Prof Nawaz MOHAMUDALLY, Modelling of need for multiple relays for ensuring seamless mobility, CEET 2014

[7] M. Kaleem GALAMALI, Assoc. Prof Nawaz MOHAMUDALLY, Investigation of prominence of placements of relays in a ubicomp topography,

[8] M. Kaleem GALAMALI, Assoc. Prof Nawaz MOHAMUDALLY, Model of energy savings achievable with location-aware transmission in ubicomp using optimised number of relays.

[9] M. Kaleem GALAMALI, Assoc. Prof Nawaz MOHAMUDALLY, Investigation of Prominence of Placements of Optimised Number of Relays in a Ubicomp Topography using Location-Aware Transmission, CEET 2015.

[10] M. Kaleem GALAMALI, Assoc. Prof Nawaz MOHAMUDALLY, Extending Node Battery Availability in Ubicomp with Location-Aware Transmission, CEET 2015.

[11] M. Kaleem GALAMALI, Assoc. Prof Nawaz MOHAMUDALLY, Extending Node Battery Availability in Ubicomp with Location-Aware Transmission using Location Refresh Intervals, CEET 2015.

[12] M. Kaleem GALAMALI, Assoc. Prof Nawaz MOHAMUDALLY, Extending Node Battery Availability in Ubicomp with Location-Aware Transmission using Uniformly Placed Relays, CEET 2015.

[13] M. Kaleem GALAMALI, Assoc. Prof Nawaz MOHAMUDALLY, Extending Node Battery Availability in Ubicomp with Location-Aware Transmission Using Optimally Placed Relays, CEET 2015.

[14] M. Kaleem GALAMALI, Assoc. Prof Nawaz MOHAMUDALLY, Model of Sender Node Energy Savings Achievable with Location-Aware MANET Transmission in Ubicomp. ACCN 2016

[15] M. Kaleem GALAMALI, Assoc. Prof Nawaz MOHAMUDALLY, Model of Overall Node Energy Savings Achievable with Location-Aware MANET Transmission in Ubicomp. ACCN 2016

[16] M. Kaleem GALAMALI, Assoc. Prof Nawaz MOHAMUDALLY, Model of Sender Node Extra Energy Savings Achievable in MANET Against Direct Node-toNode Transmission Using Location-Aware Transmission in Ubicomp. ACCN 2016

[17] M. Kaleem GALAMALI, Assoc. Prof Nawaz MOHAMUDALLY, Model of Overall Node Extra Energy Savings Achievable in MANET against Direct Node-toNode Transmission Using Location-Aware Transmission in Ubicomp. ACCN 2016

[18] M. Kaleem GALAMALI, Assoc. Prof Nawaz MOHAMUDALLY, Model of Energy Consumption Ratio Achievable in MANET Using Location-Aware Transmission in Ubicomp. ACCN 2016

[19] M. Kaleem GALAMALI, Assoc. Prof Nawaz MOHAMUDALLY, Model of Minimum Energy Consumption Ratio Achievable in MANET Using LocationAware Transmission in Ubicomp. ACCN 2016

[20] M. Kaleem GALAMALI, Assoc. Prof Nawaz MOHAMUDALLY, Model of Maximum Energy Consumption Ratio Achievable in MANET Using Location- 
Aware Transmission in Ubicomp. ACCN 2016

[21] M. Kaleem GALAMALI, Assoc. Prof Nawaz MOHAMUDALLY, Model of Overall Energy Consumption Fairness Ratio Achievable in MANET Using LocationAware Transmission in Ubicomp. ACCN 2016

[22] M. Kaleem GALAMALI, Assoc. Prof Nawaz MOHAMUDALLY, Model of Overall Energy Consumption Fairness Proportion Achievable in MANET Using LocationAware Transmission for Ubicomp, CEET 2016

[23] M. Kaleem GALAMALI, Assoc. Prof Nawaz MOHAMUDALLY, Model of Minimum Fairness Proportion Achievable in MANET Using Location-Aware Transmission for Ubicomp, CEET 2016

[24] M. Kaleem GALAMALI, Assoc. Prof Nawaz MOHAMUDALLY, Model of Maximum Fairness Proportion Achievable in MANET Using Location-Aware Transmission for Ubicomp, CEET 2016

[25] M. Kaleem GALAMALI, Assoc. Prof Nawaz MOHAMUDALLY, Model of Sender Fairness Proportion Achievable in MANET Using Location-Aware Transmission for Ubicomp, CEET 2016

[26] M. Kaleem GALAMALI, Assoc. Prof Nawaz MOHAMUDALLY, Model of Distance Travelled by packets in MANETs using Location-Aware Transmission for Ubicomp, CEET 2016

[27] M. Kaleem GALAMALI, Assoc. Prof Nawaz MOHAMUDALLY, Model of Maximum CBR Distance Travelled by packets in MANETs using Location-Aware Transmission for Ubicomp, CEET 2016

[28] M. Kaleem GALAMALI, Assoc. Prof Nawaz MOHAMUDALLY, Model of Minimum CBR Distance Travelled by packets in MANETs using Location-Aware Transmission for Ubicomp, CEET 2016

[29] M. Kaleem GALAMALI, Assoc. Prof Nawaz MOHAMUDALLY, Model of Range CBR Distance Experienced by Transmissions in MANETs using LocationAware Transmission for Ubicomp, CEET 2016

[30] M. Kaleem GALAMALI, Assoc. Prof Nawaz MOHAMUDALLY, Trend Analyses of Parameters of Equations for Sender Node Energy Savings Achievable in ubicomp MANETs using Location-Aware Transmission, ACCN 2017.

[31] M. Kaleem GALAMALI, Assoc. Prof Nawaz MOHAMUDALLY, Trend Analyses of Parameters of Equations for Overall Node Energy Savings Achievable in ubicomp MANETs using Location-Aware Transmission, ACCN 2017

[32] M. Kaleem GALAMALI, Assoc. Prof Nawaz MOHAMUDALLY, Trend Analyses of Parameters of Equations for Sender Node Extra Energy Savings Achievable in MANET against Direct Node-to-Node Location-Aware Transmission, ACCN 2017.

[33] M. Kaleem GALAMALI, Assoc. Prof Nawaz MOHAMUDALLY, Trend Analyses of Parameters of Equations for Overall Nodes Extra Energy Savings Achievable in MANET against Direct Node-to-Node Location-Aware Transmission, ACCN 2017.

[34] Markus Bylund and Zary Segall, Towards seamless mobility with personal servers, 2004

[35] Masugi Inoue, Mikio Hasegawa, Nobuo Ryoki and Hiroyuki Morikawa, Context-Based Seamless Network and Application Control, 2004

[36] Xiang Song, Umakishore Ramachandran, MobiGo: A Middleware for Seamless Mobility, College of Computing Georgia Institute of Technology, Atlanta, GA, USA, August 2007

[37] Budzisz, Ferrús, R., Brunstrom A., Grinnemo, K, Fracchia, R., Galante, G., and Casadevall, F. Towards transport-layer mobility: Evolution of SCTP multihoming, March 2008

[38] Paul Dourish \& Genevieve Bell, Divining a digital future, 2011.

[39] Xiang Song, Seamless Mobility In Ubiquitous Computing Environments, PhD Thesis, Georgia Institute of Technology, August 2008

[40] Kevin O Mahony, Jian Liang, Kieran Delaney, User-Centric Personalization and Autonomous Reconfiguration Across Ubiquitous Computing Environments, NIMBUS Centre Cork Institute of Technology, Cork, Ireland, UBICOMM 2012
[41] Pablo Vidales, Seamless mobility in 4G systems, Technical Report, University of Cambridge, Computer Laboratory, Number 656, November 2005

[42] João Pedro Sousa and David Garlan, Aura: An Architectural Framework for User Mobility in Ubiquitous Computing Environments, School of Computer Science, Carnegie Mellon University, USA, August 2002

[43] Dennis Lupiana, Ciaran O'Driscoll, Fredrick Mtenzi, Defining Smart Space in the Context of Ubiquitous Computing, Dublin Institute of Technology, Ireland, Specia Issue on ICIT 2009 Conference - Web and Agent Systems, 2009

[44] N.S.V.Shet1, Prof.K.Chandrasekaran2 and Prof. K.C.Shet3, WAP Based Seamless Roaming In Urban Environment with Wise Handoff Technique, International Journal of UbiComp (IJU), Vol.1, No.4, October 2010

[45] Yipeng Yu Dan He Weidong Hua Shijian Li Yu Qi Yueming Wang Gang Pan, FlyingBuddy2: A Braincontrolled Assistant for the Handicapped, Zhejiang University, UbiComp'12, September 5-8, 2012.

[46] Jing Su, James Scott, Pan Hui, Jon Crowcroft, Eyal de Lara Christophe Diot, Ashvin Goel, Meng How Lim, and Eben Upton, Haggle: Seamless Networking for Mobile Applications, 2007

[47] Rui Han, Moustafa M. Ghanem, Li Guo, Yike Guo*, Michelle Osmond, Enabling cost-aware and adaptive elasticity of multi-tier cloud applications, Future Generation Computer Systems, 2012

[48] Byrav Ramamurthy, K. K. Ramakrishnan , Rakesh K. Sinha, Cost and Reliability Considerations in Designing the NextGeneration IP over WDM Backbone Networks, 2012.

[49] Bhavish Aggarwal, Aditya Akella, Ashok Anand, Athula Balachandran, Pushkar Chitnis, Chitra Muthukrishnan, Ram Ramjee and George Varghese, EndRE: An End-System Redundancy Elimination Service for Enterprises, NSDI 2010, San Jose, CA

[50] Ashok Anand, Vyas Sekar and Aditya Akella, SmartRE: An Architecture for Coordinated Network-wide Redundancy Elimination, SIGCOMM 2009, Barcelona, Spain

[51] John Breeden II, "Smart-phone battery life could double without better batteries", Nov 14, 2012

[52] Andy Boxall, "When will your phone battery last as long as your kindle", December 5, 2012

[53] Imielinski, T. and Navas, J.C. (1999). GPS-based geographic addressing, routing, and resource discovery. Comms. ACM, Vol. 42, No. 4, pp. 86-92.

[54] Hightower, J. and Borriello, G. (2001). Location Systems for Ubiquitous Computing. IEEE Computer, Vol. 34, No. 8 August, pp. 57-66.

[55] Harter, A., Hopper, A., Steggles, P., Ward, A. and Webster, P. (2002). The Anatomy of a Context-Aware Application. Wireless Networks, Vol. 8, No. 2-3, Mar-May, pp. 187-197.

[56] Hightower, J., Brumitt, B. and Borriello, G. (2002). The Location Stack: A Layered Model for Location in Ubiquitous Computing. Proceedings of the 4th IEEE Workshop on Mobile Computing Systems \& Applications (WMCSA 2002), Callicoon, NY, USA, June, pp. 22-28.

[57] Graumann, D., Lara, W., Hightower, J. and Borriello, G (2003). Real-world implementation of the Location Stack: The Universal Location Framework. Proceedings of the 5th IEEE Workshop on Mobile Computing Systems \& Applications (WMCSA 2003), Monterey, CA, USA, October, pp. $122-128$

[58] Ko, Y., \& Vaidya, N. H. (2000). Location-aided routing (LAR) in mobile ad hoc networks. Wireless Networks, 6(4), 307-321.

[59] Liao, W.-H., Tseng, Y.-C., \& Sheu, J.-P. (2001). GRID: a fully location-aware routing protocol for mobile ad hoc networks. Telecommunication Systems, 18(1), 37-60.

[60] Kuhn, F., Wattenhofer, R., Zhang, Y., \& Zollinger, A. (2003). Geometric ad-hoc routing: of theory and practice. In Proceedings of the ACM (PODC'03) (pp. 63-72).

[61] Jiang, X., \& Camp, T. (2002). Review of geocasting 
protocols for a mobile ad hoc network. In Proceedings of the Grace Hopper Celebration (GHC).

[62] Ko, Y. \& Vaidya, N. H. (1999). Geocasting in mobile ad hoc networks: location-based multicast algorithms. In Proceedings of the IEEE (WMCSA'99) (pp. 101).

[63] Mauve, M., Fuler, H., Widmer, J., \& Lang, T. (2003). Position-based multicast routing for mobile ad-hoc networks (Technical Report TR-03-004). Department of Computer Science, University of Mannheim.

[64] Xu, Y., Heidemann, J., \& Estrin, D. (2001). Geographyinformed energy conservation for adhoc routing. In Proceedings of the ACM/IEEE (MOBICOM'01) (pp. 70-84).

[65] Hu, Y.-C., Perrig, A., \& Johnson, D. (2003). Packet leashes: a defense against wormhole attacks in wireless ad hoc networks. In Proceedings of the INFOCOM' 03 (pp. 19761986).

[66] Patwari, N., Hero III, A. O., Perkins, M., Correal, N. S., \& O'Dea, R. J. (2003). Relative location estimation in wireless sensor networks. IEEE Transactions on Signal Processing, 51(8), 2137-2148.

[67] Baldauf, M., Dustdar, S., \& Rosenberg, F. (2007). A Survey on Context Aware Systems. International Journal of Ad Hoc and Ubiquitous Computing, Inderscience Publishers. forthcoming. Pre-print from: http://www.vitalab.tuwien.ac.at/ florian/papers/ijahuc2007.pdf

[68] Hong, D., Chiu, D.K.W., \& Shen, V.Y. (2005). Requirements elicitation for the design of context-aware applications in a ubiquitous environment. In Proceedings of ICEC'05 (pp. 590-596).

[69] Neeraj Tantubay, Dinesh Ratan Gautam and Mukesh Kumar Dhariwal, A Review of Power Conservation in Wireless Mobile Ad hoc Network (MANET)", International Journal of computer Science Issues, Vol 8, Issue 4, No 1, July 2011.

[70] Wenrui Zhao, Mostafa Ammar and Ellen Zegura, "A Message Ferrying Approach for Data Delivery in Sparse Mobile Ad Hoc Networks", MobiHoc'04, May 24-26, 2004, Roppongi, Japan.

About Author (s):

Associate Professor Nawaz Mohamudally works at University of Technology, Mauritius (UTM) and has undertaken supervision of MPhil/PhD Students for many years.

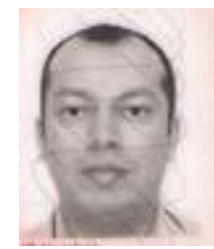

M. Kaleem Galamali is a part-time student (achieved M Phil Transfer on 28.10.2014, currently $\mathrm{PhD}$ student) at UTM under supervision of A.P. Nawaz Mohamudally. 